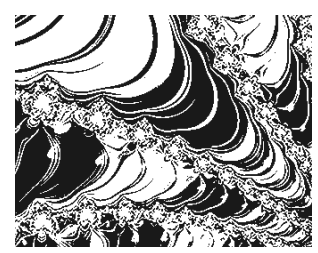

https://doi.org/10.5559/di.30.2.04

\title{
DIGITAL TECHNOLOGY USE DURING THE COVID-19 PANDEMIC AND ITS RELATIONS TO SLEEP QUALITY AND LIFE SATISFACTION IN CHILDREN AND PARENTS
}

Marina KOTRLA TOPIĆ

Institute of Social Sciences Ivo Pilar - Regional Center Osijek, Osijek, Croatia

Vanesa VARGA, Sara JELOVČIĆ

Catholic University of Croatia, Zagreb, Croatia

UDK: 159.963.2-021.465(497.5):004.77: [616.98:578.828COVID-19] Izvorni znanstveni rad

Primljeno: 29. 9. 2020.

This work has been supported in part by Croatian Science Foundation under the project number UIP-2019-04-7547 Digital technology in the family: patterns of behaviour and effects on the child development.
This research aimed to examine digital technology (DT) use, sleep quality (SQ), and the correlations between these variables in children and parents, in Croatia during the lockdown. Furthermore, it aimed to determine parental life satisfaction (LS) and its relation to DT use. In an online questionnaire, 281 parents of children ( 3 to 14 years old) provided information about the duration of DT activities throughout the pandemic, compared to the time before the pandemic, the time spent using digital devices in a typical day, and SQ for themselves and their children, as well as the estimates of personal LS. The results show that the relationship between DT use and SQ during the lockdown differs between parents and children. More time spent using DT devices is not related to $S Q$ in parents, and more time spent on smartphones is positively associated with parents' LS. In children, the prolonged use of smartphones for leisure is negatively linked to SQ. These results call for caution in allowing children longer screen time.

Keywords: digital technology, life satisfaction, lockdown, sleep quality

Marina Kotrla Topić, Institute of Social Sciences Ivo Pilar Regional Center Osijek, Šamačka 9/II, 31000 Osijek, Croatia. 
On March 11th, the World Health Organization declared a pandemic caused by the SARS-CoV-2 virus. The consequences of the pandemic, especially the impact of the measures referring to the isolation and social distancing, can be observed in households and families since they spend a great amount of time together while working and attending online schools (Van Bavel et al., 2020; Di Giorgio et al., 2020). Carroll et al. (2020) showed that during the pandemic $74 \%$ of mothers and $61 \%$ of fathers reported an increase in DT use, and Sun et al. (2020) showed that $46.8 \%$ of participants reported an increased dependence on Internet use. The prolonged use of DT can be related to "escapism", and regarded as a coping mechanism during the pandemic, similarly to the use of psychoactive substances and other reinforcing behavior (Király et al., 2020; Sun et al., 2020). In the context of Affective Neuroscience Theory, Montag and Elhai (2020) suggest that due to parents' involvement in their work from home, and the lack of daycare for children during the lockdown, many children faced a lack of parental care and more sadness caused by this neglect. Care and sadness in this case are considered as two of the seven elementary emotional systems homologously conserved across the mammalian brain. Additionally, children's usual leisure activities were often replaced by screen time activities, again due to the lockdown. These researchers highlight the indirect effect of prolonged screen time during the pandemic, such as less mammalian rough and tumble play outside, more expressed sadness, and even anger related to parental neglect (Montag \& Elhai, 2020).

We know from previous research that prolonged use of smartphones is negatively related to good SQ (Amez et al., 2020; Lanaj et al., 2014; Rod et al., 2018). The research also shows that daily interruptions by technology, affect emotional and relational well-being in the parents of young children. The parents who reported more frequent technology interruptions by phones during the day also reported poorer relationship quality, a greater conflict over technology use, fewer positive face-to-face interactions, and more negative mood (McDaniel \& Drouin, 2019). However, some studies show that richer communication, even by phones and video calls can be positively associated with life satisfaction (Goodman-Deane et al., 2016). The research shows that the relationship of Internet addiction, as the most severe type of DT overuse, with life satisfaction, is reciprocal, with Internet addiction affecting life satisfaction and vice-versa (Senol-Durak \& Durak, 2011). Lachmann et al. (2016) surveyed problematic Internet use and life satisfaction with 4852 participants and showed that, while all the correlations between life satisfaction facets and problem- 
DRUŠ. ISTRAŽ. ZAGREB GOD. 30 (2021), BR. 2, STR. 249-269

KOTRLA TOPIĆ, M. ET AL.: DIGITAL TECHNOLOGY... atic Internet use were negative, there was also a significant gender effect, showing that for females almost all of the correlations were significantly stronger.

The increase in screen time during the lockdown has been spotted in children as well, with studies showing that the average screen time for children of all ages increased from 3 hours a day before the lockdown to nearly 6 hours during the lockdown (Parents Together, 2020). This increase is often related to online schooling and study-related activities (Brom et al., 2020; Andrew et al., 2020). While spending time on the Internet for different purposes can be entertaining and can help reduce stress and anxiety (Dong et al., 2020), we know from previous research that prolonged use of DT is related to different health and mental problems, but also poorer sleep outcomes in infants, toddlers, and preschoolers (Janssen et al., 2020). In adolescence, the frequent use of DT might be negatively related to weekday sleep duration, frequent early awakening, and difficulty in falling asleep (Arora et al., 2014). Sleep is considered particularly important for learning and memory, as well as for its impact on emotional regulation and behavior (Cain \& Gradisar, 2010).

While the research clearly shows that the prolonged use of DT can have negative effects on different aspects of physical and mental health, referring both to adults and children, the question remains if the same applies to the pandemic and the lockdown. In other words, in a time when whole families are being restrained to their homes, encouraged not to go outside and to practice strict social distancing even with other family members, e.g. in a time when they are being swiftly taken out of their usual routines, with schools and businesses closed, in a time of great fear and anxiety, DT might appear to have the role of a "savior". In Croatia, there is one specific circumstance that elevated the stress level to an even higher point during the lockdown. It was the earthquake that took place in the nation's capital of Zagreb on March 22, affecting around one-third of the population in the country. During that specific time, it was DT that enabled children and their parents to continue their education and work, to communicate, to stay informed and, finally, to relax and to entertain themselves in their free time.

This research aimed to examine the characteristics of DT use in parents and children, their sleep quality, and the relationships between these variables, in Croatia during the lockdown (the period between March 16th and May 18th 2020, when most of the schools were closed). In addition, parental life satisfaction and its relationship to the use of DT in the same period, were researched. 


\section{Procedure}

Data were collected through an anonymous online survey as part of the research "Challenges of digital technology use in the family during the Covid-19 pandemic". The data were collected by the research team of the project "Digital technology in the family: Patterns of behavior and effects on children's development" (D.E.C.I.D.E.; UIP-2019-04-7547). The project was funded by the Croatian Science Foundation. Participants were recruited after the Ethics committee of the Catholic University of Croatia had positively evaluated the research. There were several lines of recruiting the participants. Invitations for participation were distributed as follows: (1) They were posted on official websites, but also Facebook and Instagram pages of the Catholic University of Croatia and the project itself, (2) They were posted on various parent support Facebook pages, and (3) They were sent to kindergartens and elementary schools in Croatia. Finally, the participants were recruited through personal contacts of the research team. The questionnaire was set online using Google Forms with integrated informed consent for participation and the link to the questionnaire. Parents of children aged 3 to 14 years were invited to participate. Each parent completed the questionnaire for themselves and for one child - the oldest child in the family that is between 3 and 14 years of age. The data were collected from May 5th until May 25th 2020, during the period of restrictive measures due to the COVID-19 pandemic. The questions regarding DT use were referring to the period of "pandemic" since at that time the term "lockdown" was still not commonly used. The participants were instructed to think of the period since the restrictive measures of the Civil Protection Directorate of the Republic of Croatia were declared without reference to specific dates. DT refers to the use of computers and laptops, tablets, smartphones, TV, and game consoles.

\section{Participants}

The participants were 281 parents of children aged 3 to 14 years. There were 255 mothers (90.7\%), and 26 fathers (9.3\%). The mean age of parents was $38.48(S D=5.758)$ and the age range was from 22 to 56. Two-thirds of parents have higher education $(N=176,62.7 \%)$, with the remaining third of participants having high school or college education $(N=80(28.4 \%)$ and $N=24(8.5 \%)$ respectively). Almost one-half of them were working from home during the pandemic $(N=129,45.9 \%)$, $18.9 \%(N=48)$ were changing between work from home and 
DRUŠ. ISTRAŽ. ZAGREB GOD. 30 (2021), BR. 2, STR. 249-269

KOTRLA TOPIĆ, M. ET AL. DIGITAL TECHNOLOGY...

the workplace, and an additional 17.1\% $(N=48)$ were going to work as usual. Only $12.5 \%(N=35)$ of parents in the study were unemployed.

The children were aged from 3 to 14 years $(M=9.78, S D=$ 3.372). There were 94 (33.5\%) children attending kindergarten (aged from 3 to 7$), 100(35.6 \%)$ attending lower grades of elementary school (aged 7 to 11$)$, and $87(31 \%)$ children attending higher grades of elementary school (aged from 11 to 14). There were 158 boys (56.2\%) and 123 girls (43.8\%) and the distribution of children according to gender was even in all three age groups.

\section{Measures}

\section{Time spent in different activities using DT during lockdown}

In order to measure parent's time spent in different activities using DT during the lockdown, compared to the time before the lockdown, an eight-item scale was developed, according to the theoretical framework of Whiting and Williams (2013). The items were formulated for the study by the research team members who were familiar with the purpose of the research. The entire scale in Croatian is available in the supplementary material. Each item describes a certain activity that digital devices could be used for: (1) communication with friends and family, (2) communication with business associates (work), (3) reading informative and news sites for monitoring events around the world, (4) seeking information regarding the COVID-19 pandemic, precaution measures, etc., (5) seeking advice on how to maintain psychological and physical health, (6) entertainment, time passing and relaxing, (7) creating personal content (e.g. taking photographs, writing blogs, sharing information and expressing personal opinions and attitudes), and (8) learning and acquiring new skills and contents. The parents were asked to compare the amount of time spent in these activities during the lockdown, to the time before the lockdown, using a three-point scale (1 "less time", 2 "the same amount of time" or 3 "more time"), or to mark that they didn't use DT for such purpose. Similarly, the parents gave estimates on a three-item scale on how often their oldest child engaged in different activities using DT during the lockdown, compared to the time before the lockdown: (1) communication with friends and family, (2) communication with teachers, (3) entertainment, passing time and relaxing, (4) creating and sharing personal content and information (e.g., photographs, video clips, etc.), and (4) learning and acquiring new skills and contents. 
DRUŠ. ISTRAŽ. ZAGREB

GOD. 30 (2021), BR. 2,

STR. 249-269

KOTRLA TOPIĆ, M. ET AL. DIGITAL TECHNOLOGY...
Time spent using different devices

for work or leisure during the lockdown

For this study, there was a scale designed to assess the average amount of time that parents spent using DT devices for work (computer or laptop and smartphone) and leisure activities (computer or laptop, smartphone, TV) in a typical day during the lockdown. The parents gave their estimates using a five-point scale ( 1 "less than 1 hour", 2 "from 1 to 3 hours", 3 "from 3 to 5 hours", 4 "from 5 to 7 hours", and 5 "more than 7 hours"). Again, they could also mark that they did not use the specific digital device for such a purpose. Using the same range of answers, parents gave estimates of how long their oldest child used different digital devices for study (computer or laptop, smartphone, TV, tablet) or leisure-related activities (computer or a laptop, smartphone, TV, tablet, game console).

\section{Sleep quality}

SQ was measured using a single-item measure that was taken from the study by Snyder et al. (2018) and adapted for the purpose of this study (the scale for the answers was changed to a 5-point scale compared to the original 10-point scale). The parents were asked to rate their own and their oldest child's overall SQ (taking into account the number of sleep hours, the ease of falling asleep, the number of night awakenings, the number of earlier morning awakenings than usual, and how restful they or their child woke up in the morning) within the last 7 days using a five-point scale (from 1 "very poor" to 5 "excellent"), where a higher score indicates better/higher SQ.

\section{Life satisfaction}

LS for parents was measured using a single-item measure "How satisfied are you with your life in general?" The parents were asked to rate how satisfied they were with their life using a five-point scale (from 1 "not at all or little" to 5 "very satisfied").

\section{Data analyses}

Frequencies and percentages were used to describe the data concerning parents' assessments of their and their child's use of DT for different purposes during the pandemic, compared to the time before the pandemic, as well as their estimates of the time that they and their child spent using different digital devices for specific purposes. For children, these results were analyzed separately for the three age groups. In order to analyze relationships between the time spent using digital devices for different purposes and the parents' sleep quality and life 
DRUŠ, ISTRAŽ ZAGREB GOD. 30 (2021), BR. 2, STR. 249-269

KOTRLA TOPIĆ, M. ET AL.: DIGITAL TECHNOLOGY... satisfaction, Pearson's correlation coefficients were calculated and the Holm's Step-Down Procedure for correction of $p$-values due to multiple comparisons was applied. Only the correlations that were significant after this correction, were interpreted in the results, and the complete correlation tables are provided in the supplementary material. To analyze the relationship between parents' estimates of children's use of digital devices for different purposes and their sleep quality, partial correlation coefficients were calculated while controlling the effect of age. Although gender was not primarily considered as the study variable, gender differences in SQ in children were additionally checked. The results show that there are no gender differences in SQ (Mgirls $=4.228, M$ boys $=4.228$, $t=0.002, p=0.999)$. For parents, over $90 \%$ of participants were mothers and for the obvious reason no gender analysis was conducted.

\section{RESULTS}

\section{Parents}

One of the aims of the research was to find out how the parental activities that included the use of DT changed during the lockdown, compared to the period before the lockdown. The results are presented in Table 1.

\begin{tabular}{lrrrr}
\hline & Time & & & \\
\cline { 2 - 5 } & $\begin{array}{r}\text { Less } \\
\text { time }\end{array}$ & $\begin{array}{r}\text { The same } \\
\text { amount } \\
\text { of time }\end{array}$ & $\begin{array}{r}\text { More } \\
\text { time }\end{array}$ & $\begin{array}{r}\text { I don't use } \\
\text { DT for such } \\
\text { purposes }\end{array}$ \\
\hline Communication with friends and family & $21(7.5)$ & $136(48.4)$ & $124(44.1)$ & $0(0)$ \\
Communication with business associates (work) & $30(10.7)$ & $90(32)$ & $134(47.7)$ & $27(9.6)$ \\
Reading informative and news sites & $17(6)$ & $134(47.7)$ & $123(43.8)$ & $7(2.5)$ \\
Seeking information regarding COVID-19 pandemic & $40(14.2)$ & $74(26.3)$ & $139(49.5)$ & $28(10)$ \\
Seeking advice on how to maintain & & & & \\
$\quad$ psychological and physical health & $53(18.9)$ & $84(29.9)$ & $46(16.4)$ & $98(34.9)$ \\
Entertainment, passing time and relaxing & $40(14.2)$ & $146(52)$ & $83(29.5)$ & $12(4.3)$ \\
Creating personal content & $50(17.8)$ & $142(50.5)$ & $35(12.5)$ & $54(19.2)$ \\
Learning and acquiring new skills and contents & $24(8.5)$ & $129(45.9)$ & $105(37.4)$ & $23(8.2)$ \\
& & & &
\end{tabular}

(1) TABLE 1

Number and percentages of parent's assessments of the time spent using DT during the lockdown compared to the time before lockdown, for various purposes, $N(\%)$
The activities in which over $43 \%$ of participants reported an increase in time spent using DT during the lockdown, are: communication with both family members and work colleagues, reading informative and news sites for monitoring events around the world, and seeking and monitoring information regarding the COVID-19 pandemic, precaution measures, etc. This would imply that, for most parents, the increase in the use of DT was related to communication and information-seeking activities. Another activity for which over 
DRUŠ. ISTRAŽ. ZAGREB GOD. 30 (2021), BR. 2, STR. 249-269

KOTRLA TOPIĆ, M. ET AL.: DIGITAL TECHNOLOGY... a third of parents reported an increase in the time spent using DT, was learning and acquiring new skills and knowledge. However, around one-third of the participants never used DT to seek advice on how to maintain psychological and physical health, making this the least often practiced activity when parents were using DT.

The results on the amount of time parents spent using different devices for work and leisure activities during lockdown, are presented in Table 2.

\begin{tabular}{llrrrrrr}
\hline \multirow{2}{*}{$\begin{array}{l}\text { General } \\
\text { purpose }\end{array}$} & Device & $\begin{array}{r}\text { Less than } \\
1 \text { hour }\end{array}$ & $\begin{array}{r}1 \text { to } 3 \\
\text { hours }\end{array}$ & $\begin{array}{r}3 \text { to } 5 \\
\text { hours }\end{array}$ & $\begin{array}{r}5 \text { to } 7 \\
\text { hours }\end{array}$ & $\begin{array}{r}\text { More than } \\
7 \text { hours }\end{array}$ & $\begin{array}{r}\text { Don't use } \\
\text { the device }\end{array}$ \\
\hline Work- & Computer & $53(18.9)$ & $4(16.7)$ & $58(20.6)$ & $29(10.3)$ & $59(21)$ & $35(12.5)$ \\
-related use & Smartphone & $74(26.3)$ & $114(40.6)$ & $48(17.1)$ & $16(5.7)$ & $16(5.7)$ & $13(4.6)$ \\
Leisure- & Computer & $143(50.9)$ & $63(22.4)$ & $10(3.6)$ & $3(1.1)$ & $3(1.1)$ & $59(21)$ \\
-related use & Smartphone & $64(22.8)$ & $162(57.7)$ & $43(15.3)$ & $7(2.5)$ & $2(0.7)$ & $3(1.1)$ \\
& TV & $100(35.6)$ & $114(40.6)$ & $41(14.6)$ & $9(3.2)$ & $6(2.1)$ & $11(3.9)$ \\
& & & & & & &
\end{tabular}

(1) TABLE 2

The amount of time parents spent using different devices during lockdown for work or leisure, $N(\%)$
The results show that parents used computers for work-related activities for various amounts of time, including a period of over 7 hours a day. Smartphones were used by $40 \%$ of parents for 1 to 3 hours a day for work, and only $4 \%$ of them did not use this device for work. For leisure activities, half of the parents used a computer for less than one hour a day and a smartphone for 1 to 3 hours a day. Television was used mostly for up to three hours a day.

The results on the SQ measure ranged from 1 to 5 , and the mean result was $3.41(S D=0.975)$. Around one-half of parents in the study reported to have had a good or a very good sleep quality $(51.9 \%)$, with only $17.8 \%$ of them who had had a bad or a very bad SQ.

The results on the LS measure ranged from 1 to 5 , and the mean result was $4.02(S D=0.804)$ pointing to good life satisfaction of the parents in the study.

This research also explored the correlations between the duration of use of different digital devices, SQ, and LS in parents. The results show that there are no significant correlations between parental SQ and the duration of use of different digital devices on a typical day during the lockdown period. However, there is a significant positive correlation between LS and the use of smartphones for both work $(r=0.181$, $p=0.003)$ and leisure $(r=0.152, p=0.011)$, showing that the participants who used smartphones for both work and leisure more, reported greater LS. Also, there is a positive correlation between LS and SQ $(r=0.247, p<0.001)$, showing that the parents who slept better, also had better LS. 


\section{Children}

The time children spent using digital devices for different activities is analyzed according to different age groups of children - those attending kindergartens, lower grades, or higher grades of elementary school (Table 3 ).

\begin{tabular}{|c|c|c|c|c|c|}
\hline \multirow[b]{2}{*}{ Purpose of use } & \multirow[b]{2}{*}{ Age groups } & \multicolumn{3}{|l|}{ Time } & \multirow[b]{2}{*}{$\begin{array}{l}\text { Doesn't use } \\
\text { DT for such } \\
\text { purposes }\end{array}$} \\
\hline & & $\begin{array}{l}\text { Less } \\
\text { time }\end{array}$ & $\begin{array}{r}\text { The same } \\
\text { amount } \\
\text { of time }\end{array}$ & $\begin{array}{c}\text { More } \\
\text { time }\end{array}$ & \\
\hline \multirow{3}{*}{$\begin{array}{l}\text { Communication } \\
\text { with friends and family }\end{array}$} & Kindergarten & $2(2.1)$ & $34(36.2)$ & $34(36.2)$ & $24(25.5)$ \\
\hline & Lower grade elementary & $8(8)$ & $34(34)$ & $41(41)$ & $17(17)$ \\
\hline & Higher grade elementary & $7(8)$ & $41(47.1)$ & $39(44.8)$ & $0(0)$ \\
\hline \multirow{3}{*}{$\begin{array}{l}\text { Communication } \\
\text { with teachers }\end{array}$} & Kindergarten & $2(2.1)$ & 11(11.7) & $16(17)$ & $65(69.1)$ \\
\hline & Lower grade elementary & $6(6)$ & 9(9) & $71(71)$ & $14(14)$ \\
\hline & Higher grade elementary & $0(0)$ & $5(5.7)$ & $82(94.3)$ & $0(0)$ \\
\hline \multirow{3}{*}{$\begin{array}{l}\text { Entertainment, passing } \\
\text { time and relaxing }\end{array}$} & Kindergarten & $3(3.2)$ & $52(55.3)$ & $33(35.1)$ & $6(6.4)$ \\
\hline & Lower grade elementary & $7(7)$ & $35(35)$ & $51(51)$ & $7(7)$ \\
\hline & Higher grade elementary & $9(10.3)$ & $29(33.3)$ & $48(55.2)$ & $1(1.1)$ \\
\hline \multirow{3}{*}{$\begin{array}{l}\text { Creating and sharing } \\
\text { personal content and } \\
\text { information }\end{array}$} & Kindergarten & $6(6.4)$ & $16(17)$ & $6(6.4)$ & $66(70.2)$ \\
\hline & Lower grade elementary & $10(10)$ & $25(25)$ & $26(26)$ & $39(39)$ \\
\hline & Higher grade elementary & $11(12.6)$ & $32(36.8)$ & $31(35.6)$ & $13(14.9)$ \\
\hline \multirow{3}{*}{$\begin{array}{l}\text { Learning and acquiring } \\
\text { new skills and contents }\end{array}$} & Kindergarten & $5(5.3)$ & $32(34)$ & $22(23.4)$ & $35(37.2)$ \\
\hline & Lower grade elementary & $4(4)$ & $21(21)$ & $68(68)$ & $7(7)$ \\
\hline & Higher grade elementary & $2(2.3)$ & $21(24.1)$ & $63(72.4)$ & $1(1.1)$ \\
\hline
\end{tabular}

(1) TABLE 3

Number and percentages of parental assessments of the time the children spent using DT during the lockdown compared to the time before lockdown, for various purposes, $N(\%)$
As expected, the most obvious differences between preschool and school children, attending both lower and higher grades, are visible in parental estimates of the time spent using DT for communication with teachers and learning, and acquiring new skills and contents. According to parents' assessments, two-thirds to over $90 \%$ of children in lower and higher grades of elementary school spent more time in these activities with the help of DT, compared to the time before the lockdown. Around one-third to two-thirds of youngest children did not use DT technology for such purposes at all. The parents also estimated that from one-third to almost one-half of children in all age groups, spent more time using DT for communication with friends and family, or entertainment, passing time and relaxing, compared to the time before the lockdown. The parental estimates also show that similar percentages of children across all age groups, used DT for these activities consuming the same amount of time as before the lockdown. The activity for which fewest parents report an increase in the time of DT use for children, was creating and sharing personal content and information (e.g., photographs, video 
(1) FIGURE 1

Parental assessments of the amount of time children spent using different devices for education purposes during lockdown clips, etc.). However, in this category one can observe the age differences, e.g. more than two-thirds of kindergarten children never used DT for such purposes.

The assessments of the time children spent using different devices for school or leisure during the lockdown are presented in Figure 1 and Figure 2.

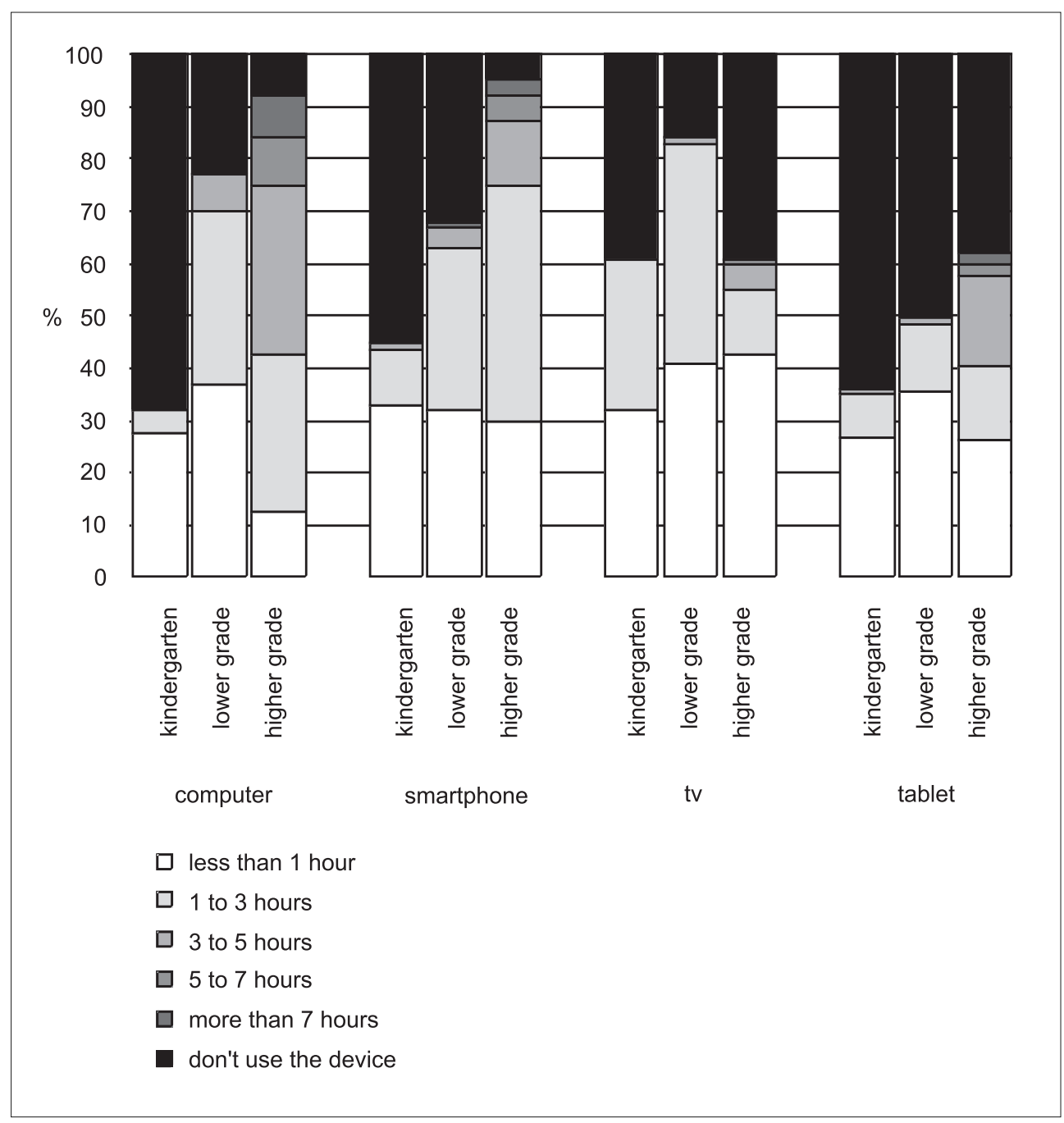

According to parental estimates, the youngest children used different digital devices rather rarely, especially computers and tablets for education purposes. When they did use any device, it was seldom for over three hours, and mostly for up to one hour. Lower-grade children used the TV for education in more cases than in any of the other age groups. Regarding other devices, there is a trend indicating that older children use more devices, and at least some of them for longer periods. 


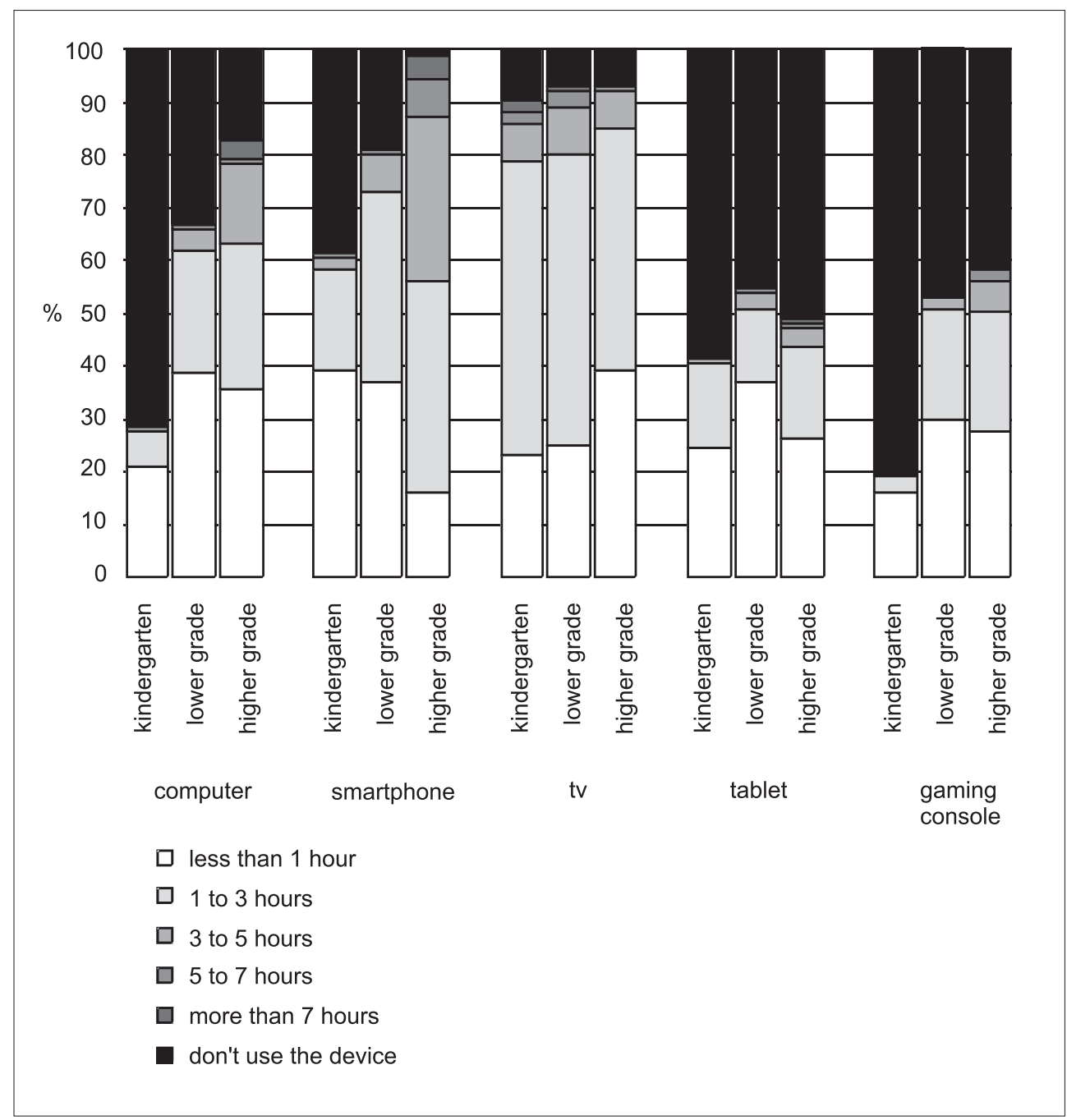

\section{(i) FIGURE 2}

Parental

assessments of the amount of time children spent using different devices for leisure activities during lockdown
For preschool-aged children and children in lower grades of elementary school, parental estimates show similar patterns of DT use for leisure activities. Children rarely used any device for longer than three hours. Also, most of them watched TV or used smartphones at least for some time, which shows that these devices were most frequently used devices for leisure activities. However, from around one-half to over two-thirds of the children never used computers, tablets, or gaming consoles, according to their parents' answers. The difference between these groups is that only one-third of the youngest children used game consoles, compared to over two-thirds of children in lower grades of elementary school. There is a similar trend in the oldest participants as well, but there are also some different preferences. For example, parents estimate 
DRUŠ. ISTRAŽ. ZAGREB GOD. 30 (2021), BR. 2, STR. 249-269

KOTRLA TOPIĆ, M. ET AL.: DIGITAL TECHNOLOGY... that tablets and game consoles were used by the least number of children in the oldest age group as well, but the use of computers was much more widespread in this age group and more children in this age group used computers and smartphones for over three hours a day for leisure activities. Except for $\mathrm{TV}$, for which parental estimates show that it was used by most children in all age groups, and tablets, which were used by around one-half of the children in all age groups, the results indicate that older children used devices more.

The quality of sleep was analyzed separately for the three age groups of children. Means and standard deviations for the kindergarten, lower grade, and higher-grade groups were $M=4.40(S D=0.845), M=4.27(S D=0.777)$, and $M=3.99$ $(S D=1.073)$, respectively. For most children in all three age groups, their parents reported them to have a good or a very good sleep quality $(90.4 \%, 88 \%$, and $78.1 \%$, respectively) with a slight indication of a trend with a less good and a very good sleep quality as the children get older. Similarly, the percentage of children for whom the parents estimated a very bad or a bad sleep quality rises a little from the youngest to the oldest age group $(5.5 \%, 4 \%$, and $9.1 \%$ respectively). The results show a significant negative correlation between sleep quality and age (Partial $r=-0.213, p<0.001$ ).

For children, there were partial correlations calculated between parental assessments of their sleep quality and DT use while controlling for the effect of age. There is a significant negative correlation between $\mathrm{SQ}$ and the use of smartphones for leisure (Partial $r=-0.458, p<0.001$; bivariate correlation coefficient $r=-0.301, p<0.001)$, meaning that children who spent more time using smartphones for leisure had lower $S Q$.

\section{DISCUSSION}

On March 16th, 2020, the Civil Protection Directorate of the Republic of Croatia issued a direction for closing all schools in Croatia. This direction that had to ensure public safety is now often referred to as a lockdown that ended up lasting over a month. Pupils gradually started to go back to school, beginning with lower grades of elementary school on May 11th, and higher grades of elementary school and high schools on May 18th. During this period, children were being educated in their homes using technology, the internet, and television, and parents had to stay at home and often work from home. They had to spend more time at home and more time using DT to communicate with their work colleagues, friends, family, teachers, etc. Indeed, the results in this study show that the most common increase in DT use for parents during lockdown was related to communication with both family mem- 
DRUŠ. ISTRAŽ. ZAGREB GOD. 30 (2021), BR. 2, STR. 249-269

KOTRLA TOPIĆ, M. ET AL.: DIGITAL TECHNOLOGY... bers and work colleagues, but also to reading informative and news sites in order to monitor events around the world and seek information regarding the COVID-19 pandemic. But parents also often report that they spent more time than before the lockdown on learning and acquiring new skills and contents. Most of the parents are mothers with high education, and in future research, it would be useful to explore whether this increase in the use of DT for learning and education might be related to their child-rearing activities - that is learning how to help their children with their online school activities. As for the time estimates referring to the use of different digital devices in parents, computers are most often used longer for work-related activities, while smartphones and television are used for leisure activities.

In parents, SQ has shown not to be related to the time spent by using different digital devices on a typical day during the lockdown period. Cellini et al. (2020) researched the changes in sleep pattern, sense of time and digital media use during the COVID-19 lockdown in Italy. The results showed that during the lockdown, there was an increase in the use of digital media close to bedtime, but this did not affect sleep habits. However, sleep timing markedly changed, since people were going to bed and waking up later, and spending more time in bed, but, paradoxically, also reporting a lower $S Q$. The increase in sleep difficulties was more pronounced for people with a higher level of depression, anxiety, and stress symptoms (Cellini et al., 2020), showing that future research should focus on individual differences in these symptoms. This also might intensify during situations such as the lockdown caused by the pandemic. These findings partially contradict previous studies that show how the use of smartphones disturbs SQ (Lanaj et al., 2014) and is potentially responsible for awakening and shorter sleep duration, which may have health consequences (Rod et al., 2018). But these studies were done in a pre-pandemic time that was very different than the lockdown period.

Additionally, the research also shows that the duration of different digital devices use in a typical day during the lockdown period is related to LS, whereby the parents who used smartphones more for both work and leisure, also reported better LS. A possible interpretation might be that those parents who were able to work from home (using smartphones), and those who more often used smartphones for leisure activities, felt more satisfaction than those, who were unable to do so for whatever reason. Previous research shows that, when it comes to adults, smartphones provide employees with instant access to work-related information and communica- 
DRUŠ. ISTRAŽ. ZAGREB GOD. 30 (2021), BR. 2, STR. 249-269

KOTRLA TOPIĆ, M. ET AL. DIGITAL TECHNOLOGY... tions outside the office, thus making them work after regular work hours (Lanaj et al., 2014.). But in a lockdown situation, access to smartphones enabled parents to work and, in the long run, feel more satisfied than the parents who used these devices for work less.

To summarize, the results show that during the lockdown, for parents there is a lack of negative relationship between the use of digital devices and SQ, and there is a positive relationship between some types of use of digital devices and LS. This suggests that circumstances of DT use should be studied deeper in different life situations, and its relationship to mental health might depend on different factors.

For children, in the two older age groups, but not the youngest one, parents estimate an increase in time of DT use for communication with teachers and learning and acquiring new skills and contents during the lockdown. These results suggest that online education might have posed a great strain on children. There is a trend showing that children in all age groups also spent more time, compared to before lockdown, using DT for communication with friends and family or entertainment, passing time, and relaxing. Other research supports these findings (Andrew et al., 2020; Moore et al., 2020; Olive et al., 2020; Pišot et al., 2020; Qin et al., 2020).

For studying, most children in lower grades used the TV at least for some time during the day. In Croatia, remote schooling for children in lower grades was organized so that each day there was a specially broadcast TV program at a specific time, when each grade level was encouraged to follow. This program was not mandatory, and it lasted for three hours for each grade level at the beginning of the lockdown to one hour a day, as the lockdown continued. Also, it was accompanied by other forms of online schooling, which varied from one class to another, depending on the teacher's demands. Students in higher grades, on the other hand, often had realtime online classes using different platforms and different devices. For leisure activities children in the two younger age groups most often used the TV and smartphone, while children in the oldest age group most often used smartphones and computers. A similar trend for preference of smartphone usage has been seen in other research as well (Kulakci-Altintas, 2020; Sivrikova et al., 2020; Zilka, 2020).

Parental reports for children indicate that prolonged use of smartphones for leisure is related to lower SQ. Sleep problems in preschool-aged children can have short-term consequences such as injury risk, behavior problems, and parental stress, and sleep loss. But they can also lead to long-term con- 
DRUŠ, ISTRAŽ. ZAGREB GOD. 30 (2021), BR. 2, STR. 249-269

KOTRLA TOPIĆ, M. ET AL.: DIGITAL TECHNOLOGY..
(Garrison et al., 2011). Contemporary research consistently proves the association between media use and child sleep problems, emphasizing high levels of use, bedtime use, and violent media content (Garrison \& Christakis, 2012). For instance, adolescents (aged 12-18 years) who reported getting more than 8 hours of sleep per night, have used technology less after 9 pm, compared to adolescents who reported getting 6 8 hours of sleep and those who reported getting 3-5 hours of sleep (Calamaro et al., 2009).

This research has presented new findings regarding children's screen time and sleep quality throughout the COVID-19 pandemic. However, there are several limitations to this study that should be noted. The participants in the study were mostly employed mothers with high education and with good SQ and LS. Therefore the findings should not be generalized without further research. The data were gathered using self-reports or parental reports and considering the social desirability of reporting low levels of use for DT, it is possible that the use of DT was underrated. Furthermore, children's SQ and their DT use were assessed by their parents and it is known from previous research that there are possible discrepancies between self-assessments and parental assessment of sleep characteristics in adolescents (Short et al., 2013). All the variables in the study were assessed using single items. The use of a single item measure for assessing sleep quality applied in this study is a practical measure with favorable measurement characteristics (Snyder et al., 2018). However, a lengthier questionnaire might have provided information that would allow a deeper understanding of sleep quality elements. The same applies to the life satisfaction measure (Pavot \& Diener, 2008). The cross-sectional design and correlation analysis prevent drawing conclusions about causality. For future research, the use of longitudinal design and different sources for data collection regarding DT are recommended. Also, different aspects of DT use should be monitored in more detail, for example, the use of DT before bedtime.

\section{CONCLUSION}

This research aimed to investigate the relations of the prolonged use of DT for study/work and leisure to SQ in parents and children, and LS in parents, during a specific period defined by the COVID-19 pandemic that resulted in a lockdown.

In monitoring the possible effects of the COVID-19 pandemic and lockdown on parents and children, one should be careful to differentiate between factors that might have produced these effects, such as: the social isolation and home containment, the decrease in physical activity, or the prolonged 
DRUŠ. ISTRAŽ. ZAGREB GOD. 30 (2021), BR. 2, STR. 249-269

KOTRLA TOPIĆ, M. ET AL. DIGITAL TECHNOLOGY... use of DT for example, and in the case of Croatia, the additional stress caused by the earthquake that affected around one-third of its population, and might have affected $40 \%$ of participants in this study (those parents coming from Zagreb). Previous research shows that social isolation can cause an emotional disturbance, sleep disorders, depressive syndromes, anxiety and stress (Urbina-Garcia, 2020). Physical activity can be linked to cognitive development, psychosocial and cardiometabolic health (World Health Organization, 2019). The prolonged use of DT can cause a range of physical and mental health problems, such as digital fatigue (Alevizou, 2020), sleep problems (Garrison \& Christakis, 2012) and the increase of body mass index (Marker et al., 2019). But during the lockdown many of these factors were interrelated. For example, children spent more time in front of screens but also less time outside (Moore et al., 2020).

The results of this research show that DT use during the lockdown is related to children's and parents' SQ in a different manner. For parents, there is no significant relationship between DT use and SQ, and there is a positive relationship between some types of DT use and LS. In children, prolonged use of smartphones for leisure is negatively linked to SQ. These results show that even in times of pandemic, parents still need to be cautious about allowing their children longer screen time because this might be negatively associated with children's SQ.

\section{SUPPLEMENTARY MATERIAL}

\section{TABLE 1}

Items from the scale measuring use of DT for different purposes

during the pandemic, compared to the time before the pandemic, for adults, in Croatia

U odnosu na razdoblje prije uvođenja mjera Civilnog stožera RH zbog pandemije bolesti COVID-19, koliko vremena Vi sada digitalnu tehnologiju koristite za:

$\begin{array}{cccc} & \text { jednako } & & \\ \text { manje } & \text { mnogo } & \text { više } & \text { ne koristim } \\ \text { vremena } & \text { vremena } & \text { vremena } & \text { u tu svrhu }\end{array}$

\begin{tabular}{|c|c|c|c|c|}
\hline komunikaciju s prijateljima i obitelji & 1 & 2 & 3 & 0 \\
\hline komunikaciju s poslovnim suradnicima (rad/posao) & 1 & 2 & 3 & 0 \\
\hline $\begin{array}{l}\text { čitanje informativnih i novinskih portala radi praćenja } \\
\text { vijesti i događanja u svijetu }\end{array}$ & 1 & 2 & 3 & 0 \\
\hline $\begin{array}{l}\text { traženje i praćenje informacija o pandemiji bolesti COVID-19, } \\
\text { mjerama zaštite i sl. }\end{array}$ & 1 & 2 & 3 & 0 \\
\hline traženje pomoći i savjeta kako očuvati fizičko i psihološko zdravlje & 1 & 2 & 3 & 0 \\
\hline zabavu, ispunjavanje vremena, opuštanje & 1 & 2 & 3 & 0 \\
\hline $\begin{array}{l}\text { stvaranje vlastitih sadržaja (npr. fotografija, blogova), } \\
\text { dijeljenje informacija, iskazivanje vlastitoga mišljenja i stavova }\end{array}$ & 1 & 2 & 3 & 0 \\
\hline učenje i edukaciju u svrhu stjecanja određenih vještina i znanja & 1 & 2 & 3 & 0 \\
\hline
\end{tabular}


TABLE 2

Correlations between the duration of different digital devices use, SQ, and LS in parents (Pearson $r$ )

\begin{tabular}{|c|c|c|c|c|c|c|c|}
\hline & & 1 & 2 & 3 & 4 & 5 & 6 \\
\hline Work-related use & $\begin{array}{l}1 \text { Computer } \\
2 \text { Smartphone }\end{array}$ & $0.284^{* *}$ & & & & & \\
\hline Leisure-related use & $\begin{array}{l}3 \text { Computer } \\
4 \text { Smartphone } \\
5 \text { TV } \\
6 \text { Sleep quality } \\
7 \text { Life satisfaction }\end{array}$ & $\begin{array}{c}0.204^{* *} \\
0.048 \\
-0.116 \\
-0.007 \\
0.114^{*}\end{array}$ & $\begin{array}{l}0.141^{*} \\
0.249^{* *} \\
0.050 \\
-0.044 \\
0.181^{* *}\end{array}$ & $\begin{array}{l}0.295^{* *} \\
0.248^{* *} \\
-0.069 \\
-0.064\end{array}$ & $\begin{array}{c}0.315^{* *} \\
-0.048 \\
0.152^{*}\end{array}$ & $\begin{array}{l}-0.085 \\
-0.013\end{array}$ & $0.247^{* *}$ \\
\hline
\end{tabular}

Notes: ${ }^{* *}$ correlation is significant at the 0.01 level (2-tailed), ${ }^{*}$ correlation is significant at the 0.05 level (2-tailed)

TABLE 3

Partial correlations between parental estimates of children's

sleep quality and DT use while controlling for the effect of children's age

\begin{tabular}{|c|c|c|c|c|c|c|c|c|c|c|}
\hline & & 1 & 2 & 3 & 4 & 5 & 6 & 7 & 8 & 9 \\
\hline $\begin{array}{l}\text { Study- } \\
\text {-related use }\end{array}$ & $\begin{array}{l}1 \text { Computer } \\
2 \text { Smartphone } \\
3 \text { TV } \\
4 \text { Tablet }\end{array}$ & $\begin{array}{c}0.436^{* *} \\
-0.086 \\
-0.282^{*}\end{array}$ & $\begin{array}{l}0.114 \\
0.191\end{array}$ & 0.154 & & & & & & \\
\hline $\begin{array}{l}\text { Leisure- } \\
\text {-related use }\end{array}$ & $\begin{array}{l}5 \text { Computer } \\
6 \text { Smartphone } \\
7 \text { TV } \\
8 \text { Tablet } \\
9 \text { Gaming console } \\
10 \text { Sleep quality }\end{array}$ & $\begin{array}{c}0.442^{* *} \\
0.122 \\
0.077 \\
-0.159 \\
0.078 \\
0.048\end{array}$ & $\begin{array}{l}0.486^{* *} \\
0.131 \\
0.078 \\
0.077 \\
0.184 \\
0.150\end{array}$ & $\begin{array}{l}0.089 \\
-0.028 \\
0.202 \\
0.449^{* *} \\
0.230 \\
0.007\end{array}$ & $\begin{array}{l}-0.138 \\
-0.231 \\
-0.132 \\
0.476^{* *} \\
0.141 \\
0.124\end{array}$ & $\begin{array}{l}0.162 \\
0.180 \\
0.068 \\
0.195 \\
0.080\end{array}$ & $\begin{array}{c}0.163 \\
-0.047 \\
0.173 \\
-0.458^{* *}\end{array}$ & $\begin{array}{r}0.231 \\
0.106 \\
-0.058\end{array}$ & $\begin{array}{l}0.418^{* *} \\
0.116\end{array}$ & -0.148 \\
\hline
\end{tabular}

Notes: ${ }^{* *}$ correlation is significant at the 0.01 level (2-tailed), ${ }^{*}$ correlation is significant at the 0.05 level (2-tailed)

\section{REFERENCES}

Alevizou, G. (2020, April 3). Virtual schooling, Covid-gogy and digital fatigue. Parenting for a Digital Future. Digital Culture $\mathcal{E}$ Education. https://blogs.lse.ac.uk/parenting4digita...

Arora, T., Broglia, E., Thomas, G. N., \& Taheri, S. (2014). Associations between specific technologies and adolescent sleep quantity, sleep quality, and parasomnias. Sleep Medicine, 15(2), 240-247. https://doi. org/10.1016/j.sleep.2013.08.799

Amez, S., Vujić, S., Soffers, P., \& Baert, S. (2020). Yawning while scrolling? Examining gender differences in the association between smartphone use and sleep quality. Journal of Sleep Research, 29(6), e12971. https://doi.org/10.1111/jsr.12971

Andrew, A., Cattan, S., Costa Dias, M., Farquharson, C., Kraftman, L., Krutikova, S., \& Sevilla, A. (2020). The gendered division of paid and domestic work under lockdown. Discussion Paper Series, No. 13500, 1-32.

Brom, C., Lukavský, J., Greger, D., Hannemann, T., Straková, J., \& Švařičck, R. (2020). Mandatory home education during the COVID-19 lockdown in the Czech Republic: A rapid survey of 1st-9th 
DRUŠ. ISTRAŽ. ZAGREB GOD. 30 (2021), BR. 2, STR. 249-269

KOTRLA TOPIĆ, M. ET AL. DIGITAL TECHNOLOGY... graders' parents. Frontiers in Education, 5(103). https://doi.org/10.3389/ feduc. 2020.00103

Cain, N., \& Gradisar, M. (2010). Electronic media use and sleep in school-aged children and adolescents: A review. Sleep Medicine, 11(8), 735-742. https://doi.org/10.1016/j.sleep.2010.02.006

Calamaro, C. J., Mason, T. B., \& Ratcliffe, S. J. (2009). Adolescents living the 24/7 lifestyle: Effects of caffeine and technology on sleep duration and daytime functioning. Pediatrics, 123(6), e1005-e1010. https://doi.org/10.1542/peds.2008-3641

Carroll, N., Sadowski, A., Laila, A., Hruska, V., Nixon, M., Ma, D. W., \& Haines, J. (2020). The impact of COVID-19 on health behavior, stress, financial and food security among middle to high income Canadian families with young children. Nutrients, 12(8), 1-14. https://doi.org/ $10.3390 /$ nu12082352

Cellini, N., Canale, N., Mioni, G., \& Costa, S. (2020). Changes in sleep pattern, sense of time and digital media use during COVID-19 lockdown in Italy. Journal of Sleep Research, 29(4), e13074. https://doi. org/10.1111/jsr.13074

Di Giorgio, E., Di Riso, D., \& Mioni, G. (2020). The interplay between mothers' and children's behavioral and psychological factors during COVID-19: An Italian study. PsyArXiv Preprints, 1-23. https://doi.org/ 10.31234/osf.io/dqk7h

Dong, H., Yang, F., Lu, X., \& Hao, W. (2020). Internet addiction and related psychological factors among children and adolescents in China during the coronavirus disease 2019 (COVID-19) epidemic. Frontiers in Psychiatry, 11, 751. https://doi.org/10.3389/fpsyt.2020.00751

Garrison, M. M., Liekweg, K., \& Christakis, D. A. (2011). Media use and child sleep: The impact of content, timing, and environment. Pediatrics, 128(1), 29-35. https://doi.org/10.1542/peds.2010-3304

Garrison, M. M., \& Christakis, D. A. (2012). The impact of a healthy media use intervention on sleep in preschool children. Pediatrics, 130(3), 492-499. https://doi.org/10.1542/peds.2011-3153

Goodman-Deane, J., Mieczakowski, A., Johnson, D. M., Goldhaber, T., \& Clarkson, P. (2016). The impact of communication technologies on life and relationship satisfaction. Computers in Human Behavior, 57, 219-229. https://doi.org/10.1016/j.chb.2015.11.053

Janssen, X., Martin, A., Hughes, A. R., Hill, C. M., Kotronoulas, G., \& Hesketh, K. R. (2020). Associations of screen time, sedentary time and physical activity with sleep in under 5s: A systematic review and meta-analysis. Sleep Medicine Reviews, 49, 101226. https://doi.org/10. 1016/j.smrv.2019.101226

Király, O., Potenza, M. N., Stein, D. J., King, D. L., Hodgins, D. C., Saunders, J. B., Griffiths, M. D., Gjoneska, B., Billieux, J., Brand, M., Abbott, M. W., Chamberlain, S. R., Corazza, O., Burkauskas, J., Sales, C. M. D., Montag, C., Lochner, C., Grünblatt, E., Wegmann, E., ... Demetrovics, Z. (2020). Preventing problematic internet use during the COVID-19 pandemic: Consensus guidance. Comprehensive Psychiatry, 100, 152180. https://doi.org/10.1016/j.comppsych.2020.152180

Kulakci-Altintas, H. (2020). Technological device use among 0-3 year 
DRUŠ. ISTRAŽ. ZAGREB GOD. 30 (2021), BR. 2, STR. 249-269

KOTRLA TOPIĆ, M. ET AL.: DIGITAL TECHNOLOGY... technological devices. Journal of Child and Family Studies, 29(1), 55-61. https://doi.org/10.1007/s10826-019-01457-x

Lachmann, B., Sariyska, R., Kannen, C., Cooper, A., \& Montag, C. (2016). Life satisfaction and problematic Internet use: Evidence for gender specific effects. Psychiatry Research, 238, 363-367. https://doi. org/10.1016/j.psychres.2016.02.017

Lanaj, K., Johnson, R. E., \& Barnes, C. M. (2014). Beginning the workday yet already depleted? Consequences of late-night smartphone use and sleep. Organizational Behavior and Human Decision Processes, 124(1), 11-23. https://doi.org/10.1016/j.obhdp.2014.01.001

Marker, C., Gnambs, T., \& Appel, M. (2019). Exploring the myth of the chubby gamer: A meta-analysis on sedentary video gaming and body mass. Social Science E Medicine, 112325. https://doi.org/10.1016/j. socscimed.2019.05.030

McDaniel, B. T., \& Drouin, M. (2019). Daily technology interruptions and emotional and relational well-being. Computers in Human Behavior, 99, 1-8. https://doi.org/10.1016/j.chb.2019.04.027

Montag, C., \& Elhai, J. D. (2020). Discussing digital technology overuse in children and adolescents during the COVID-19 pandemic and beyond: On the importance of considering Affective Neuroscience Theory. Addictive Behaviors Reports, 12, 100313. https://doi.org/10. 1016/j.abrep.2020.100313

Moore, S. A., Faulkner, G., Rhodes, R. E., Brussoni, M., Chulak-Bozzer, T., Ferguson, L. J., Mitra, R., O'Reilly, N., Spence, J. C., Vanderloo, L. M., \& Tremblay, M. S. (2020). Impact of the COVID-19 virus outbreak on movement and play behaviours of Canadian children and youth: A national survey. International Journal of Behavioral Nutrition and Physical Activity, 17(1), 1-11. https://doi.org/10.1186/s12966-020-00987-8

Olive, L., Sciberras, E., Berkowitz, T. S., Hoare, E., Telford, R., Mikocka-Walus, A., \& Wood, (2020). Child and parent physical activity, sleep and screen time during COVID-19 compared to pre-pandemic nationally representative data and associations with mental health. PsyArXiv Preprints, 1-34. https://doi.org/10.31234/osf.io/anqct

Parents Together (2020, April 23). Survey shows parents alarmed as kids 'screen time skyrockets during COVID-19 crisis. Parents Together. https://parents-together.org/survey-shows-parents-alarmed-as-kidsscreen-time-skyrockets-during-covid-19-crisis/?mod=article_inline

Pavot, W., \& Diener, E. (2008). The satisfaction with life scale and the emerging construct of life satisfaction. The Journal of Positive Psychology, 3(2), 137-152. https://doi.org/10.1080/17439760701756946

Pišot, S., Milovanović, I., Šimunič, B., Gentile, A., Bosnar, K., Prot, F., \& Bakalár, P. (2020). Maintaining everyday life praxis in the time of COVID-19 pandemic measures (ELP - COVID-19 survey). European Journal of Public Health, 30(6), 1181-1186. https://doi.org/10.1093/eurpub/ckaa157

Qin, F., Song, Y., Nassis, G. P., Zhao, L., Dong, Y., Zhao, C., \& Zhao, J. (2020). Physical activity, screen time, and emotional well-being during the 2019 novel Coronavirus outbreak in China. International Journal of Environmental Research and Public Health, 17(14), 5170. https://doi. org/10.3390/ijerph17145170 
DRUŠ. ISTRAŽ. ZAGREB GOD. 30 (2021), BR. 2, STR. 249-269

KOTRLA TOPIĆ, M. ET AL. DIGITAL TECHNOLOGY...
Rod, N. H., Dissing, A. S., Clark, A., Gerds, T. A., \& Lund, R. (2018). Overnight smartphone use: A new public health challenge? A novel study design based on high-resolution smartphone data. PloS ONE, 13(10), e0204811. https://doi.org/10.1371/journal.pone.0204811

Senol-Durak, E., \& Durak, M. (2011). The mediator roles of life satisfaction and self-esteem between the affective components of psychological well-being and the cognitive symptoms of problematic Internet use. Social Indicators Research, 103, 23-32. https://doi.org/10. 1007/s11205-010-9694-4

Short, M. A., Gradisar, M., Lack, L. C., Wright, H. R., Chatburn, A. (2013). Estimating adolescent sleep patterns: Parent reports versus adolescent self-report surveys, sleep diaries, and actigraphy. Nature and Science of Sleep, 5, 23-26. https://doi.org/10.2147/NSS.S38369

Sivrikova, N. V., Ptashko, T. G., Perebeynos, A. E., Chernikova, E. G., Gilyazeva, N. V., \& Vasilyeva, V. S. (2020). Parental reports on digital devices use in infancy and early childhood. Education and Information Technologies, 25, 3957-3973. https://doi.org/10.1007/s10639-020-10145-z

Snyder, E., Cai, B., DeMuro, C., Morrison, M. F., \& Ball, W. (2018). A new single-item sleep quality scale: Results of psychometric evaluation in patients with chronic elementaryinsomnia and depression. Journal of Clinical Sleep Medicine, 14(11), 1849-1857. https://doi.org/10. 5664/jcsm.7478

Sun, Y., Li, Y., Bao, Y., Meng, S., Sun, Y., Schumann, G., Kosten, T., Strang, J., Lu, L., \& Shi, J. (2020). Brief report: Increased addictive internet and substance use behavior during the COVID-19 pandemic in China. The American Journal on Addictions, 29(4), 268-270. https://doi. org/10.1111/ajad.13066

Urbina-Garcia, A. (2020). Young children's mental health: Impact of social isolation during the COVID-19 lockdown and effective strategies. PsyArXiv Preprints, 1-12. https://doi.org/10.31234/osf.io/g549x

Whiting, A. i Williams, D. (2013). Why people use social media: A uses and gratifications approach. Qualitative Market Research, 16(4), 362-369. https://doi.org/10.1108/QMR-06-2013-0041

Van Bavel, J. J., Baicker, K., Boggio, P. S., Capraro, V., Cichocka, A., Cikara, M., \& Drury, J. (2020). Using social and behavioural science to support COVID-19 pandemic response. Nature Human Behaviour, 4, 460-471. https://doi.org/10.1038/s41562-020-0884-Z

Zilka, G. C. (2020). Always with them: Smartphone use by children, adolescents, and young adults - characteristics, habits of use, sharing, and satisfaction of needs. Universal Access in the Information Society, 19(1), 145-155. https://doi.org/10.1007/s10209-018-0635-3 
DRUŠ. ISTRAŽ. ZAGREB GOD. 30 (2021), BR. 2, STR. 249-269

KOTRLA TOPIĆ, M. ET AL.: DIGITAL TECHNOLOGY...

\section{Upotreba digitalne tehnologije tijekom pandemije COVID-19 i povezanost s kvalitetom spavanja te zadovoljstvom životom kod djece i roditelja}

Marina KOTRLA TOPIĆ

Institut društvenih znanosti Ivo Pilar - Područni centar Osijek, Osijek, Hrvatska

Vanesa VARGA, Sara JELOVČı́́

Hrvatsko katoličko sveučilište, Zagreb, Hrvatska

Cili je ovog istraživanja bio ispitati obiliežja upotrebe digitalne tehnologije (DT), kvalitete spavanja (KS) i zadovoljstva životom (ZŽ) te korelacije između ovih varijabli kod djece i roditelja tijekom restriktivnih miera. $U$ online upitniku 281 roditelj djece od 3 do 14 godina dao je procjene o trajanju upotrebe DT-a za aktivnosti tijekom pandemije u usporedbi s trajanjem prije pandemije, trajanju upotrebe digitalnih uređaja tijekom tipičnoga dana te o kvaliteti spavanja za sebe i svoju djecu, kao i procjene o osobnom ZŽ-u. Rezultati pokazuju kako upotreba DT-a tijekom restriktivnih miera nema isti obrazac povezanosti sa KS-om kod roditelja i djece. Za roditelje nema značajne povezanosti između upotrebe DT-a i KS-a te postoji pozitivna povezanost između trajanja upotrebe pametnih telefona $\mathrm{i}$ ZŽ-a. Kod djece je dulja upotreba pametnih telefona za zabavu negativno povezana sa KS-om. Rezultati pozivaju na oprez prilikom dopuštanja dulje upotrebe DT-a za djecu, čak i tijekom zatvaranja.

Ključne riječi: digitalna tehnologija, zadovoljstvo životom, restriktivne mjere, kvaliteta spavanja

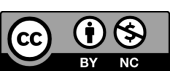

Međunarodna licenca / International License:

Imenovanje-Nekomercijalno / Attribution-NonCommercial 